\title{
Estrogen signaling effects on muscle- specific immune responses through controlling the recruitment and function of macrophages and T cells
}

Zhao Hong Liao ${ }^{1+}$, Tao Huang ${ }^{1+}$, Jiang Wei Xiao ${ }^{1}$, Rui Cai Gu', Jun Ouyang ${ }^{1}$, Gang Wu²* and Hua Liao ${ }^{1 *}$

\begin{abstract}
Background: Estrogen signaling is indispensable for muscle regeneration, yet the role of estrogen in the development of muscle inflammation, especially in the intramuscular T cell response, and the influence on the intrinsic immuno-behaviors of myofibers remain largely unknown. We investigated this issue using the mice model of cardiotoxin (CTX)-induced myoinjury, with or without estrogen level adjustment.

Methods: CTX injection i.m. (tibialis anterior, TA) was performed for preparing mice myoinjury model. Injection s.c. of $17 \beta$-estradiol $\left(E_{2}\right)$ or estrogen receptor antagonist 4-OHT, or ovariectomy $(\mathrm{OVX})$, was used to change estrogen level of animal models in vivo. Serum $E_{2}$ level was evaluated by ELISA. Gene levels of estrogen receptor (ERs) and cytokines/chemokines in inflamed muscle were monitored by QPCR. Inflammatory infiltration was observed by immunofluorescence. Macrophage and T cell phenotypes were analyzed by FACS. Immunoblotting was used to assess protein levels of ERs and immunomolecules in $\mathrm{C}_{2} \mathrm{C}_{12}$ myotubes treated with $\mathrm{E}_{2}$ or 4-OHT, in the presence of IFN- $\gamma$.

Results: We monitored the increased serum $E_{2}$ level and the upregulated ER $\beta$ in regenerated myofibres after myotrauma. The absence of estrogen in vivo resulted in the more severe muscle inflammatory infiltration, involving the recruitment of monocyte/macrophage and $\mathrm{CD}^{+} \mathrm{T}$ cells, and the heightened proinflammatory (M1) macrophage. Moreover, estrogen signaling loss led to Treg cells infiltration decrease, Th1 response elevation in inflamed muscle, and the markedly expression upregulation of immunomolecules in IFN- $\gamma$-stimulated $\mathrm{C}_{2} \mathrm{C}_{12}$ myotubes in vitro.

Conclusion: Our data suggest that estrogen is a positive intervention factor for muscle inflammatory response, through its effects on controlling intramuscular infiltration and phenotypes of monocytes/macrophages, on affecting accumulation and function of Treg cells, and on suppressing Th1 response in inflamed muscle. Our findings also imply an inhibition effect of estrogen on the intrinsic immune behaviors of muscle cells.
\end{abstract}

Keywords: Estrogen, Myoinjury, Inflammation, Estradiol $\left(E_{2}\right), C_{2} C_{12}$ cell

\footnotetext{
*Correspondence: Wugang_wugang@126.com; hua-liao@163.com

†Zhao Hong Liao and Tao Huang contributed equally to this work.

${ }^{2}$ Department of Emergency, NanFang Hospital, Southern Medical University, Guangzhou 510515, China

'Guangdong Provincial Key Laboratory of Medical Biomechanics, Department

of Anatomy, Southern Medical University, Guangzhou 510515, China
}

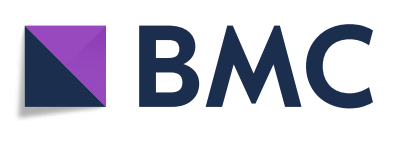

(c) The Author(s). 2019 Open Access This article is distributed under the terms of the Creative Commons Attribution 4.0 International License (http://creativecommons.org/licenses/by/4.0/), which permits unrestricted use, distribution, and reproduction in any medium, provided you give appropriate credit to the original author(s) and the source, provide a link to the Creative Commons license, and indicate if changes were made. The Creative Commons Public Domain Dedication waiver (http://creativecommons.org/publicdomain/zero/1.0/) applies to the data made available in this article, unless otherwise stated. 


\section{Background}

Estrogen play an essential role in regulating immune response, through its interactions with the receptors on the immune cells which affects the production, maturation, differentiation, and ultimately the functioning of immune cells [1-3]. Generally, estrogen stimulates the production of immunoglobulins by plasma cells [4], and directly upregulates the expression of mediators of B cell survival, such as CD22, SHP-1, and Bcl-2 and impairs mediators of B cell apoptosis such as PD-1 [5-8]. On the other hand, estrogen exerts repressive effects on the innate immune, by increasing regulatory $\mathrm{T}$ cells (Tregs) frequency and number [9], controlling the expression of certain chemokine receptors in $\mathrm{T}$ cells [10], repressing monocytes and neutrophils to secrete proinflammatory cytokines in response to activating stimuli [11-13], or impairing natural killer (NK) cell cytotoxicity [14]. Taken together, these findings suggest that estrogen signaling is important in establishing the balance of immunity and tolerance.

An important and persistent finding has been that males and females respond differently following traumatic injury, with a relative protection afforded to females $[15,16]$. After acute trauma, an early elevation of estrogen levels had been reported [17-19]. Our previous work evidenced that the alterations in the serum estradiol $\left(E_{2}\right)$ levels is correlated with the severity of trauma and craniocerebral injury and, thus probably, could serve as an indicator for the evaluation of the trauma severity and possibly in prognosis [20]. The evidence from animal models also revealed that estrogen might have an important role in injury healing by directly modifying the local inflammatory and immune reaction. For example, estrogen was reported to (i) reduce the number of wound neutrophils and diminish neutrophil localization at sites of inflammation [21], and (ii) augment estrogen receptor activity in immune cells and dampen innate immune signaling pathways in peripheral dendritic cells and macrophages [22-24]. But anyway, it is still incompletely delineated how the estrogen milieu effects on the immune response trajectory of the damaged peripheral tissue soon after injury.

Acute trauma always involves in skeletal muscle injury, triggers the severe muscle inflammation, swelling, and muscle fiber degeneration $[25,26]$. Ideal muscle regeneration and repair is favorable for recovering movement function and improving life quality of trauma patients. Skeletal muscle is a target tissue for estrogen, which expresses both ERs $(\mathrm{ER} \alpha$ and ER $\beta)[27,28]$, and in mice ER $\beta$ is the predominant isoform [28]. $\mathrm{E}_{2}$ is suggested to promote proliferation and differentiation of skeletal muscle myoblasts which express functional estrogen receptors [29]. Estrogen signaling is indispensable for muscle regenerative processes, since this hormone mediates protein synthesis and satellite cell activation, and regulates metabolic homeostasis and insulin sensitivity in skeletal muscle $[30,31]$. However, whether in vivo estrogen alteration after acute muscle injury is directly associated with muscle inflammation procedure, especially with intramuscular $\mathrm{T}$ cell response, and even associated with the intrinsic immuno-behaviors of myofibres remain largely unknown.

In this study, we explored the role of estrogen signaling on mice acute muscle inflammatory response induced by cardiotoxin (CTX) injection. We monitored the increased serum $E_{2}$ level in mice suffered from myoinjury, and the upregulated ER $\beta$ in regenerated myofibres in damaged tibialis anterior (TA) muscle. By in vivo administration of the recombinant $17 \beta$-estradiol, estrogen receptor antagonist 4-OHT, or using ovariectomy (OVX) model of female mice, we artificially elevated or blocked serum $\mathrm{E}_{2}$ level in vivo. We showed that estrogen signaling contributed to control intramuscular infiltration of monocytes/macrophages, and the transition of proinflammatory M1 to the anti-inflammatory M2 macrophages. Moreover, we found that estrogen signaling affected on accumulation and function of Treg cells, suppresses Th1 response in damaged muscle, and regulates the intrinsic immune capacities of muscle cells. Combined, our data demonstrate an essential role for estrogen signaling in suppression of the acute damage triggered-muscle inflammation and immune response.

\section{Methods}

\section{Mouse strains}

C57BL/6 (B6) mice were obtained from Animal Experimentation Centre of the Southern Medical University. Mice were housed in a specific pathogen-free barrier facility and were analyzed between 8 and 16 weeks of age. Animal experiments were approved by the local institutional ethic committee for animal experimentation.

\section{Animal experiments}

For preparing CTX-induced myoinjury, mice were injected $30 \mu \mathrm{l}$ CTX $(30 \mu \mathrm{g} / \mathrm{ml}$, Sigma-Aldrich, USA) into the TA muscles. To interfere with estrogen level in vivo, we used the recombinant $\beta$-estradiol $\left(E_{2}, E 2758\right.$, SigmaAldrich, USA), or estrogen receptor antagonist, 4Hydroxytamoxifen (4-OHT, T176, Sigma-Aldrich, USA). One day after CTX injection, animals received $\mathrm{E}_{2}(50 \mu \mathrm{l} /$ mouse/day, $50 \mu \mathrm{g} / \mathrm{ml}$ ) or $4-\mathrm{OHT}(50 \mu \mathrm{l} / \mathrm{mouse} /$ day, $2 \mathrm{mg} / \mathrm{ml}$ ) daily subcutaneous injection (s.c.), respectively $[32,33]$. For preparing ovariectomy (OVX) mice, female mice $(8 \mathrm{w})$ were kept under anesthesia by intraperitoneal (i.p.) administration of ketamine $(90 \mathrm{mg} / \mathrm{kg})$ and xylazine (4.5 mg/kg). A ventral incision between two and three nipples on each side was made and then ovaries were removed slowly. After closing the wound, 22,000 IU/kg penicillin was injected. The sham group underwent the 
same procedure without removal of the ovaries. Plasma $E_{2}$ level of treated mice were detected by ELISA analysis. OVX mice further received CTX injection into TA muscles on day 14 post-ovariectomy. Mice were sacrificed on day $0,1,3,7,10,15$, or 20 after myoinjury. TA muscle specimens were collected and snap frozen for gene and protein analysis, or homogenized for cell sorting. For histology, muscle samples were directly frozen in liquid nitrogen-cooled isopentane. For assessing macrophages phagocytosis capacity, female OVX mice or untreated control mice further received $50 \mu \mathrm{l}$ Lumispheres (Lum, 1: 200, $5 \mathrm{mg} / \mathrm{ml}$, BeiSiLe, China) injection into TA muscles 1 day after CTX injection. Mice were sacrificed on day 3, and analyzed by flow cytometry.

\section{RNA preparation and qRT-PCR}

After cervical dislocation, bilateral TA muscles were rapidly dissected out and dipped immediately into RNAlater (RNeasy Protect Mini Kit, Qiagen) to protect RNA from degradation. The muscles were weighted and incubated overnight at $4{ }^{\circ} \mathrm{C}$, then transferred to TRIzol and deep freezed at $-80{ }^{\circ} \mathrm{C}$ prior to further analysis.

One microgram of total RNA samples from muscle tissue or $\mathrm{C}_{2} \mathrm{C}_{12}$ myotubes was used for reverse transcription (RT) with commercially available kit (RevertAid First Strand cDNA Synthesis Kit, Fermentas). Real-time polymerase chain reaction (PCR) was performed in triplicate with an ABI StepOne Plus system (Applied Biosystems, USA) and a fluorescence-labeled SYBR Green/ROX qPCRMaster Mix kit (Fermentas) for IL-1, IL-6, IL-10, TGF- $\beta$, MCP- 1, MIP- $1 \alpha$, SLPI, TNF- $\alpha$, TGF- $\beta 2$, PPAR $\gamma$, IL-1 $\beta$, IFN- $\gamma$, IL-4, IL-17, T-bet, IRF4, STAT3, ER $\alpha$, and ER $\beta$ and with glyceraldehyde-3-phosphate dehydrogenase (GAPDH) taken as an endogenous control (primer sequences and sizes of amplicons are listed in Table 1). The results were analyzed with SOS2.1 software (Applied Biosystems). Expression of the genes was calculated from the accurate threshold cycle $(\mathrm{Ct})$. The $\mathrm{Ct}$ values for $\mathrm{GAPDH}$ were compared with those from IL-1, IL-6, IL-10, TGF- $\beta$, MCP-1, MIP- $1 \alpha$, SLPI, TNF- $\alpha$, TGF- $\beta 2$, PPAR $\gamma$, IL- $1 \beta$, IFN- $\gamma$, IL-4, IL-17, T-bet, IRF4, STAT3, ER $\alpha, E R \beta$, and in each well to calculate $\Delta \mathrm{Ct}$. Data of the treated conditions were expressed relative to the signal obtained for the average of the untreated controls by the $\Delta \Delta \mathrm{Ct}$ calculation. The triplicate $\Delta \Delta \mathrm{Ct}$ values for each sample were averaged.

\section{Histological and immunofluorescence detection}

Snap-frozen whole TA muscle was transversely cryo-sectioned, with the thickness of $8 \mu \mathrm{m}$, and either stained with hematoxylin and eosin or prepared for immunostaining. For immunofluorescence, muscle was fixed with cold acetone and incubated with rat anti-mouse monoclonal antibodies against CD11b (1:200, eBioscience, California, USA), F4/80 (1:200, eBioscience,
Table 1 Primer sequences for qRT-PCR

\begin{tabular}{|c|c|}
\hline Genes & Primer sequence \\
\hline \multirow[t]{2}{*}{ |L-1 } & Forward(5'-3'): GCCCATCCTCTGTGACTC \\
\hline & Reverse(3'-5'): TGTGCCGTCTTTCATTAC \\
\hline \multirow[t]{2}{*}{ IL-6 } & Forward(5'-3'): GGCAATTCTGATTGTATG \\
\hline & Reverse(3'-5'): CTCTGGCTTTGTCTTTCT \\
\hline \multirow[t]{2}{*}{ MCP-1 } & Forward(5'-3'): GGGTCCAGACATACATTAA \\
\hline & Reverse(3'-5'): ACGGGTCAACTTCACATT \\
\hline \multirow[t]{2}{*}{ IL-10 } & Forward(5'-3'): TाTCAAACAAAGGACCAG \\
\hline & Reverse(3'-5'): GGATCATTTCCGATAAGG \\
\hline \multirow[t]{2}{*}{ MIP-1a } & Forward(5'-3'): CTGCCCTTGCTGTTCTTC \\
\hline & Reverse(3'-5'): CAAAGGCTGCTGGTTTCA \\
\hline \multirow[t]{2}{*}{ TGF- $\beta$} & Forward(5'-3'): GGCGGTGCTCGCTITGTA \\
\hline & Reverse(3'-5'): TCCCGAATGTCTGACGTATTGA \\
\hline \multirow[t]{2}{*}{ SLPI } & Forward(5'-3'): AAGCCACAATGCCGTACTGACTG \\
\hline & Reverse(3'-5'): ACAGGATTCACGCACTTGGAACC \\
\hline \multirow[t]{2}{*}{ TNF-a } & Forward(5'-3'): GGCGGTGCCTATGTCTCA \\
\hline & Reverse(3'-5'): CCTCCACTTGGTGGTTTGT \\
\hline \multirow[t]{2}{*}{ TGF- $\beta 2$} & Forward(5'-3'): GGCGGTGCTCGCTITGTA \\
\hline & Reverse(3'-5'): TCCCGAATGTCTGACGTATTGA \\
\hline \multirow[t]{2}{*}{ PPARY } & Forward(5'-3'): CGCCAAGGTGCTCCAGAAGATG \\
\hline & Reverse(3'-5'): GGTGAAGGCTCATGTCTGTCTCTG \\
\hline \multirow[t]{2}{*}{ IL-1 $\beta$} & Forward(5'-3'): GCCCATCCTCTGTGACTC \\
\hline & Reverse(3'-5'): TGTGCCGTCTITCATTAC \\
\hline \multirow[t]{2}{*}{ IFN- $\gamma$} & Forward(5'-3'): CATTGAAAGCCTAGAAAGTCTG \\
\hline & Reverse(3'-5'): CTCATGAATGCATCCTITTCG \\
\hline \multirow[t]{2}{*}{ |L-17 } & Forward(5'-3'): GAGCTTCATCTGTGTCTCTGAT \\
\hline & Reverse(3'-5'): GCCAAGGGAGTTAAAGACTTTG \\
\hline \multirow[t]{2}{*}{ IRF4 } & Forward(5'-3'): AATGGTTGCCAGGTGACAGGAAC \\
\hline & Reverse(3'-5'): CGCCAAGGCTTCAGCAGACC \\
\hline \multirow[t]{2}{*}{ STAT3 } & Forward(5'-3'): GACTGATGAAGAGCTGGCTGACTG \\
\hline & Reverse(3'-5'): TCCAGACGGTCCAGGCAGATG \\
\hline \multirow[t]{2}{*}{$\mid \mathrm{L}-4$} & Forward(5'-3'): GGT CTC AAC CCC CAG CTA GT \\
\hline & Reverse(3'-5): TAGTGAACTCTCTCTAGTAGCCG \\
\hline \multirow[t]{2}{*}{ T-bet } & Forward(5'-3'): TCAACCAGCACCAGACAGAG \\
\hline & Reverse(3'-5'): AAACATCCTGTAATGGCTTGTG \\
\hline \multirow[t]{2}{*}{ ERa } & Forward(5'-3'): ACTGGCCAATCTITCTCTGC \\
\hline & Reverse(3'-5): CAATTCATCCCCAAAGACATGGAC \\
\hline \multirow[t]{2}{*}{$E R \beta$} & Forward(5'-3'): TCACTTCTGCGCTGTCTGCAGCG \\
\hline & Reverse(3'-5'): CCTGGGTCGCTGTGCCAAG \\
\hline \multirow[t]{2}{*}{ GAPDH } & Forward(5'-3'): TGCTCGCTGTATTCTTGGTG \\
\hline & Reverse(3'-5'): GGCTCCTTCTGTCGAGTGAC \\
\hline
\end{tabular}

California, USA), CD4 (1:200, BD or eBioscience, USA), or rabbit polyclonal anti-ER $\alpha$ (1:400, Abcam, USA); mouse monoclonal anti-ER $\beta$ (1:200, Abcam, USA), rabbit antimouse CD3ع (1:200, Abcam, Cambridge, UK), rabbit 
polyclonal anti-Dystrophin (1:400, Santa Cruz, California, USA), Alexa Fluor 488-conjugated goat anti-rat IgG (1: 400, Santa Cruz, California, USA), Alexa Fluor 488-conjugated goat anti-rabbit IgG (1:400, Santa Cruz, California, USA), Cy3-conjugated goat anti-rabbit IgG (1:400, Santa Cruz, California, USA), Cy3-conjugated goat anti-rat IgG (1:400, Santa Cruz, California, USA), Alexa Fluor 555-conjugated donkey anti-mouse IgG (1:500, Beyotime, China), Alexa Fluor 555-conjugated donkey anti-rabbit IgG (1: 500, Beyotime, China), FITC-conjugated goat anti-mouse IgG (1:400, eBioscience, USA), or FITC-conjugated goat anti-rabbit IgG (1:400, Santa Cruz, USA) were used as secondary antibodies. Nuclei were counterstained with DAPI. Slides were viewed with an Olympus BX51 fluorescence microscope (Olympus, Japan). For the intensity analysis, the Image-Pro Plus software was performed to quantify the intensity of staining. The integrated optical density (IOD) and area of interest (AOI) of all the positive staining were measured, respectively. The mean density (IOD/ AOI) was then calculated.

\section{Cell sorting and flow cytometry analysis}

Damaged TA muscles were collected and minced and then gently digested with $0.2 \%$ IIcollagenase at $37{ }^{\circ} \mathrm{C}$ for $45 \mathrm{~min}$ twice. Total cells isolated from muscle homogenate were re-suspended in fluorescence-activated cell sorting buffer (phosphate buffer solution, $0.5 \%$ bovine serum albumin, $2 \mathrm{mM}$ EDTA) to obtain a single-cell suspension. After Fc receptor blocking with anti-CD16/CD32 (Biolegend, USA), cells were incubated with anti-CD45-Pacific Blue, anti-F4/ 80-PE, anti-Ly-6C-FITC, anti-CD11b-PE, anti-CD3ع-APC, anti-CD4-FITC, anti-IFN- $\gamma$-PE, anti-IL-4-APC, anti-IL$17 \alpha-P E-C y 7$, anti-CD25-PE, anti-Foxp3-APC (1:100, ThermoFisher, USA), anti-T-bet-BV421(1:100, BD Biosciences, USA), anti-CTLA-4-APC (1:100, eBioscience, California, USA), anti-MHC-II-eFluor 450 (1:100, eBioscience, California, USA), and anti-CX3CR1-APC (1:100, Bioss, China). Labeled cells were analyzed with a FACSAria II cell sorter (BD Biosciences, USA) and FlowJo software. For cell sorting, mice were sacrificed on day 3 and 6 after CTXmyoinjury. Muscle samples were collected, minced, and incubated with anti-CD45-Pacific Blue and anti-F4/80-PE on day 3, or incubated with anti-CD3e-APC and anti-CD4FITC on day 6. $\mathrm{CD} 45^{+} \mathrm{F} 4 / 80^{+}$cells, or $\mathrm{CD} 3 \varepsilon^{+} \mathrm{CD} 4^{+}$cells were sorted by MoFlo XDP, for further RNA preparation and qRT-PCR analysis.

\section{$C_{2} C_{12}$ cell culture, proinflammatory stimuli, and the interference with $\mathrm{E}_{2}$ or 4-OHT}

$\mathrm{C}_{2} \mathrm{C}_{12}$ cells (ATCC, USA) were cultured in Dulbecco's modified Eagle's medium Nutrient Mixture F-12 (DMEM/ F12, Hyclone) containing with $10 \%$ fetal bovine serum (FBS, Gbico), 100 units $/ \mathrm{ml}$ penicillin, and $100 \mu \mathrm{g} / \mathrm{ml}$ streptomycin sulfate in a $5 \% \mathrm{CO}_{2}$-humidified chamber
(Heraeus, Germany) at $37{ }^{\circ} \mathrm{C}$. For differentiation studies, $\mathrm{C}_{2} \mathrm{C}_{12}$ cells were cultured in DMEM, added with $2 \%$ horse serum (Gibco, USA) for $72 \mathrm{~h}$. For proinflammatory stimuli, cells were treated with IFN- $\gamma(0.6 \mu \mathrm{g} / \mathrm{ml}, \mathrm{R} \& \mathrm{D}, \mathrm{USA})$. For in vitro estrogen interference analysis, $E_{2}(1.0 \mathrm{nM})$ or 4-OHT $(0.1 \mu \mathrm{M})$ [34] were added to the corresponding medium supplemented with IFN- $\gamma$, respectively. Cells were analyzed after $48 \mathrm{~h}$ culturing with IFN- $\gamma$.

\section{Western blot analysis}

Cell or tissue protein extraction was performed according to the manufacturer's protocol (KeyGEN, China). Protein concentrations were evaluated using a BCA assay kit (KeyGEN, China). Equal amounts of proteins were electrophoresed on 6-12\% SDS-polyacrylamide gel and transferred to Immobilon $\mathrm{P}$ membrane (Millipore, USA). Membranes were blocked in 5\% non-fat dried milk in Tris-buffered saline/Tween-20 (TBS-T: $20 \mathrm{mM}$ Tris, $\mathrm{pH}$ 7.5, $150 \mathrm{mM} \mathrm{NaCl}, 0.05 \%$ Tween-20) for $1 \mathrm{~h}$ at RT. The following antibodies were used for detection: mouse monoclonal anti-TLR3(1:1000, NOVUS, USA); rabbit polyclonal anti-H-2K $\mathrm{K}^{\mathrm{b}}$ (1:1000, Abcam, Cambridge, UK); mouse monoclonal anti-H2-Ea (1:400, Santa Cruz, USA); rabbit polyclonal anti-ER $\alpha$ (1:1000, Abcam, USA); mouse monoclonal anti-ER $\beta$ (1:1000, Abcam, USA); or mouse monoclonal anti-GAPDH (1:4000, KANGCHEN, China). Primary antibodies were incubated for $12 \mathrm{~h}$ at $4{ }^{\circ} \mathrm{C}$ in $5 \%$ non-fat dried milk in TBS-T. The membrane was then washed three times in TBS-T and incubated for $1 \mathrm{~h}$ at RT with horseradish peroxidase conjugated goat anti-rabbit IgG (1:5000, Fudebio, China) or goat anti-mouse IgG (1: 2000, CST, USA), in 5\% non-fat dried milk in TBS-T. After washing three times in TBS-T, the protein bands were visualized by enhanced chemiluminescence (ECL) detection reagents (Applygen Technologic Inc., China). Immunoreactive bands was detected by the ECL detection system (Protein Simple, USA), and densitometric values were analyzed with ImageJ v1.42 software (National Institutes of Health, USA). Relative expression of each immunoreactive band was calculated by comparison with GAPDH.

\section{ELISA analysis}

Mouse blood was collected by retrobulbar vein puncture in the presence of ethylenediamine tetra-acetic acid. Samples were chilled on ice and then plasma-separated by centrifugation at $48{ }^{\circ} \mathrm{C}$ for $20 \mathrm{~min}$. Samples was taken for ELISA test of the total estradiol concentration according to the manufacturer's procedure (the ER EIA kit, R\&D, USA). Firstly, the plate was incubated with estradiol primary antibody. Then $100 \mu \mathrm{l}$ of the standard, control, or samples were added into the appropriate wells on the plate. Further, $50 \mu \mathrm{l}$ of the estradiol conjugate was then added to all wells and covered with the 
adhesive strip for 2-h incubation at room temperature on the shaker. After that, each well received $200 \mu \mathrm{l}$ substrate solution and incubated about $30 \mathrm{~min}$ at room temperature on the benchtop, protecting from light. Finally, $100 \mu \mathrm{l}$ stop solution was added to each well. The optical density of each well was determined within $30 \mathrm{~min}$, using a microplate reader set to $450 \mathrm{~nm}$. The amount of signal was directly proportional to the standard level of estradiol in the assay buffer solution.

\section{Statistical analysis}

All data are expressed as mean \pm standard deviation (SD). One-way ANOVA was used for multiple comparisons (Duncan's multiple range test) using SPSS ver.13.0 software. $P$ values $<0.05$ were considered as statistically significant.

\section{Results}

Acute myoinjury induces the enhancement of serum estrogen level and estrogen receptor $\operatorname{Er} \beta$ expression in damaged muscle and in regenerated myofibres

Using $H \& E$ and Dystrophin fluorescence staining, we observed that CTX injection in tibialis anterior (TA) muscle of B6 mice induced myofiber necrosis and degeneration at 3 days post-injury. Damage was gradually replaced by smaller regenerating myofibers, and centrally nucleated myofibers became prominent on day 7 and 10 (Fig. 1a). Conspicuous mononuclear cell infiltration was detected on both day 3 and 7 (Fig. 1a).

It has been shown that the serum estradiol $\left(E_{2}\right)$ level elevated in the early stage of the trauma for the adult male and female patients, which suggests that estrogen may play an important role in protecting vital organs of traumatic patients [17-19]. By means of ELISA assay, we found that serum $E_{2}$ levels significantly increased for male and female mice on day $1,3,7$, and 10 post-injury $\left(\mathrm{E}_{2}\right.$ peak values presented on day 7 ), but rapidly decreased on day 15 and 20, compared to that of healthy mice (Fig. 1b), which reflected an early evolving of estrogen signaling in acute injury-induced muscle inflammation procedure. To further establish this point, we turned to qRT-PCR analysis of estrogen receptors (ERs) gene expression in damaged TA muscle, and demonstrated that mRNA levels of estrogen receptor ER $\alpha$ were always lower-expressed after myoinjury, while ER $\beta$ gene levels were quite lower in control and $3 \mathrm{~d}$ damaged muscle, but their levels gradually elevated, and presented peak value at the day 7 and 10 (Fig. 1c), suggesting that ER $\beta$-related estrogen signaling was recruited in response to muscle damage.

We next explored ER $\alpha$ and ER $\beta$ expression in damaged muscle through immunofluorescence analysis, and observed that ER $\alpha$ and ER $\beta$ low-expressed in mature myofibers from healthy mice (Fig. 1d). However, CTX treatment induced the increased protein expression of $\mathrm{ER} \beta$, but not for ER $\alpha$, in infiltrated mononuclear cells $\left(\mathrm{CD} 11 \mathrm{~b}^{+}\right)$and in regenerated centronuclear myofibers (Dystrophin $^{+}$), as compared to healthy TA muscle (Fig. 1d). To definitely determine whether muscle cells upregulate estrogen signaling in inflammatory milieu, we cultured $\mathrm{C}_{2} \mathrm{C}_{12}$ myoblasts in IFN- $\gamma$-constructed proinflammatory milieu, and proved that IFN- $\gamma$-induced $\mathrm{ER} \beta$ protein levels increase in $\mathrm{C}_{2} \mathrm{C}_{12}$ myotubes $(2 \%$ horse serum administration) (Fig. 1e).

\section{In vivo estrogen signaling interferes with proinflammatory macrophages recruitment and function after muscle injury}

Previous studies have shown that estrogen signaling controls crucial processes in immune and inflammatory response $[2,4,12,14]$. For investigating the in vivo effects of estrogen on muscle inflammation, we next artificially elevated or decreased $E_{2}$ level in vivo, by injecting s.c. of the recombinant $\beta$-estradiol, or its antagonist 4OHT following CTX treatment, respectively. In addition, ovariectomy (OVX) was performed in female mice to get the constant serum $\mathrm{E}_{2}$ level decrease in vivo before muscle damage. As expectedly, through ELISA test, we confirmed $\beta$-estradiol induced serum $\mathrm{E}_{2}$ concentration increase in male and female mice separately (Fig. 2a). As reported by Wang $\mathrm{Y}$ et al. [35], we found serum $\mathrm{E}_{2}$ level of female mice markedly decreased on day 14 post-OVX (Fig. 2a). We did not find the marked difference of muscle inflammation response between $\beta$-estradiol administrated and control mice with CTX treatment alone (Fig. 2b); instead, our data indicated that in the absence of estrogen signaling, muscle inflammation was aggravated. Histological analysis showed that 4-OHT injection delayed muscle repair: centrally nucleated myofibers were still prominent on day 15 , and muscle architecture was not yet fully repaired at this time point. Indeed, 4OHT treatment initiated a more sustained and severe inflammatory response in TA muscle, and inflammatory cells were still observed on day 15 post-injury (Fig. 2b). Similar to what was seen in female mice treated with 4OHT, the delayed muscle repair and the aggravated inflammation were also observed in damaged muscle of female mice that received OVX (Fig. 2b).

Since muscle injury and healing encompass the recruitment of inflammatory cells, and the inflammatory response to acute myoinjury is an innate immune response $[36,37]$, we next investigated whether estrogen signaling interferes with the intramuscular infiltration of monocytes/macrophages after CTX injection. We conducted immunostaining to assess the infiltration of $\mathrm{CD}_{11} \mathrm{~b}^{+}$and $\mathrm{F} 4 / 80^{+}$cells in CTX-damaged muscles of $\mathrm{B} 6$ mice with or without $\beta$-estradiol and 4-OHT treatment, or OVX mice on day 3 and 7 post-injury. The extent of infiltration was 


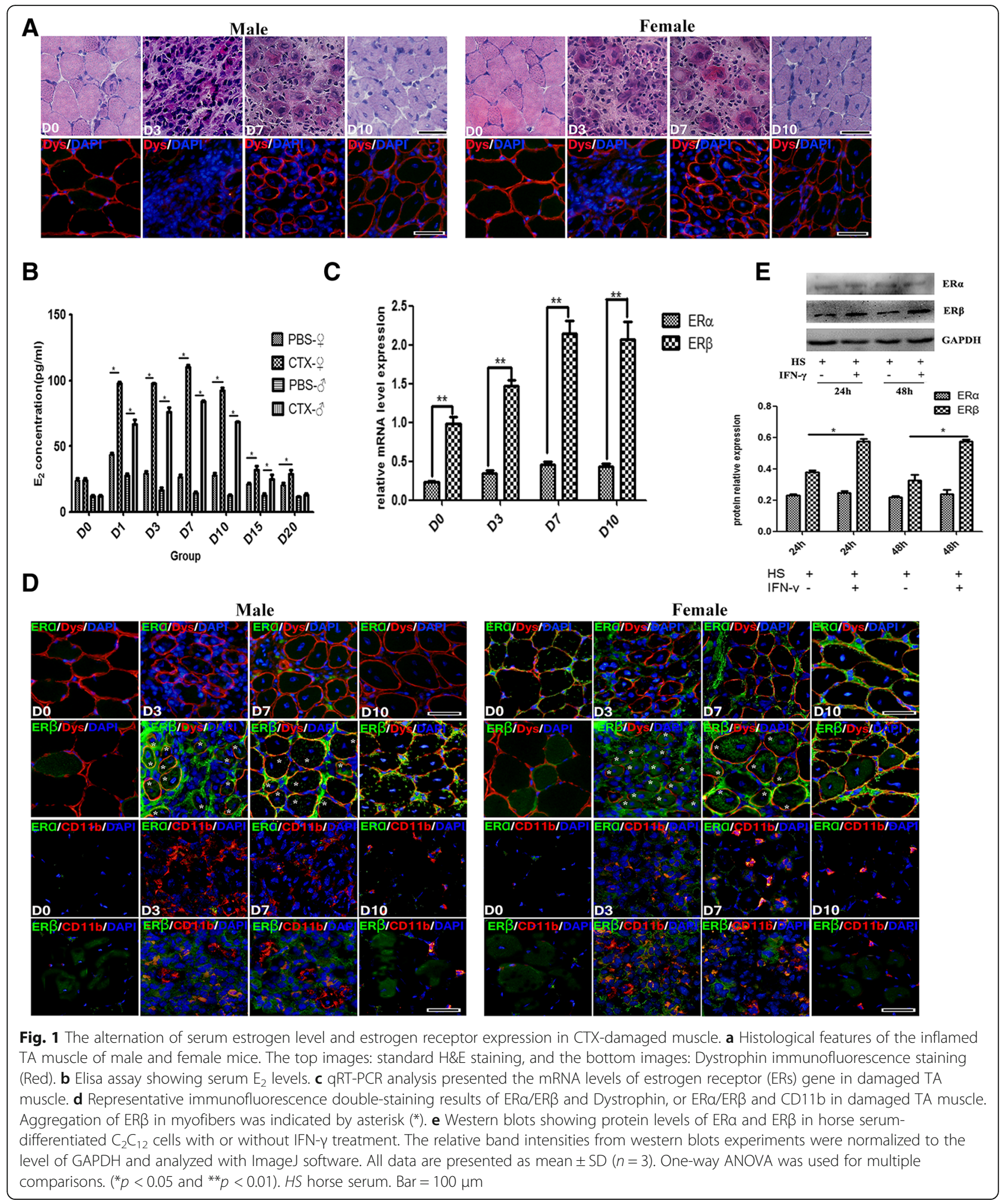

evaluated by fluorescent staining intensity analysis. Despite of the similar numbers of inflammatory cells and fluorescence intensity in damaged muscle between $\beta$-estradiol-treated and the control mice, we observed a dramatic increase for $\mathrm{CD} 11 \mathrm{~b}^{+}$and $\mathrm{F} 4 / 80^{+}$cells in inflamed muscle of mice administrated with 4-OHT, and of OVX mice (Fig. 2c). In line with the immunostaining results, using FACS analysis, we also monitored the increase of 


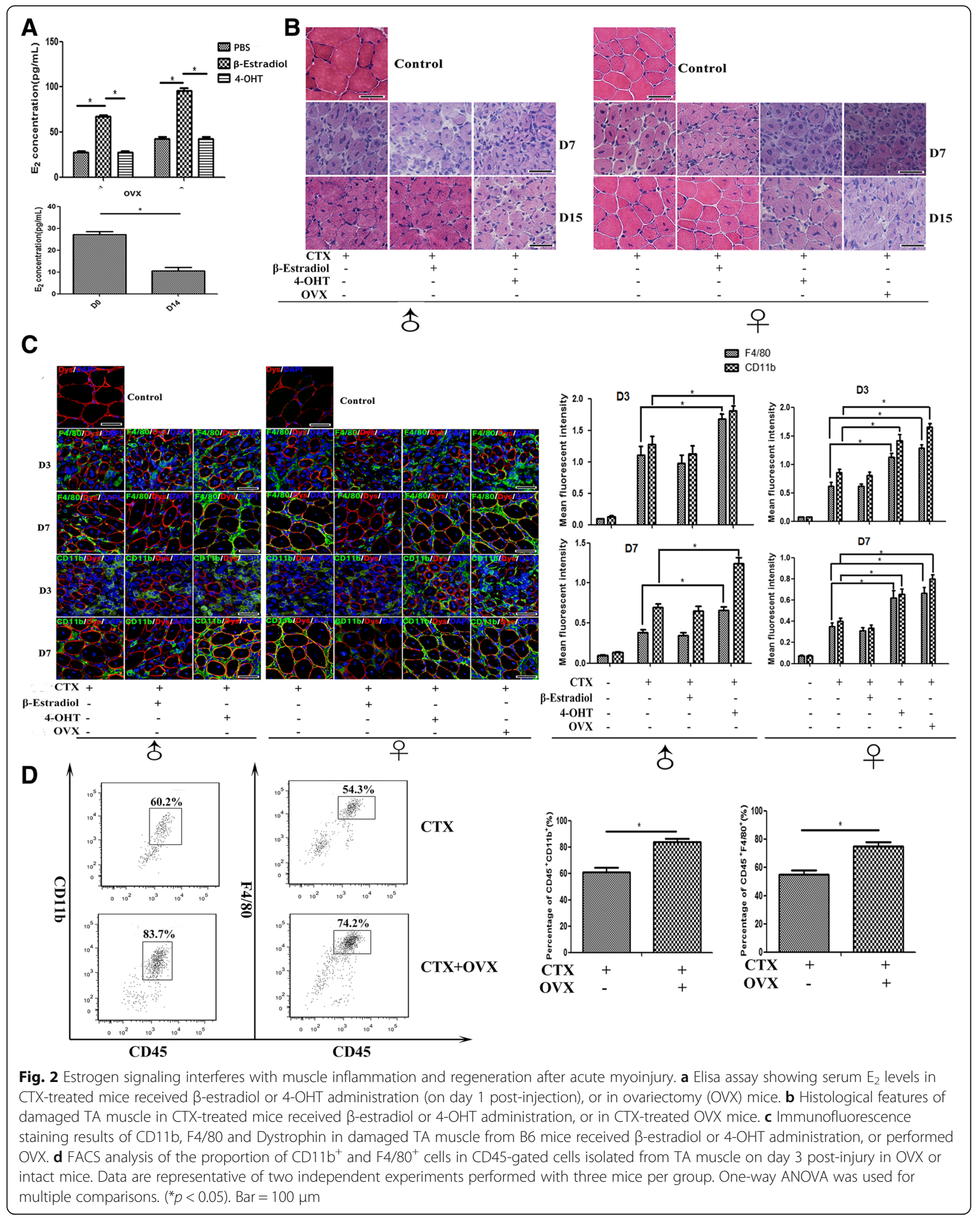


$\mathrm{CD} 11 \mathrm{~b}^{+}$and $\mathrm{F} 4 / 80^{+}$cells population, in damaged muscle of ovariectomized female mice, compared to control mice (Fig. 2d).

To further determine whether estrogen signaling effects on infiltrated macrophage phenotype, $\mathrm{CD} 45^{+}$cells were isolated from 3d-damaged TA muscle of female mice receiving ovariectomy or not, labeled with FITCor PE-conjugated antibodies against Ly-6C or F4/80, and analyzed by FACS. Not surprisingly, our results showed a higher proportion of $\mathrm{F} 4 / 80^{+} \mathrm{Ly}-6 \mathrm{C}^{+}$cells in damaged muscle of ovariectomized mice, than that of untreated mice (Fig. 3a). When we turned to address the effects of estrogen signaling on macrophage function, we found that in the absence of estrogen signaling, the gene levels of classical M1-type factors in isolated $\mathrm{CD} 45^{+} \mathrm{F} 4 / 80^{+}$ cells, involving IL-1 $\beta$, SLPI, and MCP-1, but not of M2type factors (TNF- $\alpha$, TGF- $\beta 2$, IL-10, PPAR $\gamma$ ), markedly elevated (Fig. 3b). Since MHC-II ${ }^{+}$macrophages are primarily proinflammatory cells in inflamed muscle, and peaked in number at early phase of regeneration after myoinjury [38], we next monitored MHC-II expression in isolated cells. As presented in Fig. 3c, the higher proportions of $\mathrm{F} 4 / 80^{+} \mathrm{MHC}-\mathrm{II}^{+}$cells were gated from $\mathrm{CD} 45^{+}$cells isolated from inflamed muscle of ovariectomized mice, than that of untreated mice. As well, in F4/ $80^{+}$cells from inflamed muscle of ovariectomized mice, we observed the lower expression of CX3CR1, than that of untreated mice (Fig. 3d). These data suggested that estrogen signaling contributes to myoinjury-induced inflammatory infiltration, and maybe favorable for the transition of infiltrated macrophages from proinflammatory M1 to the anti-inflammatory M2 phenotype in damaged muscle.

Previous studies have demonstrated that phagocytic capacity of macrophages is depressed following trauma, whereas administration of estrogen improves macrophage phagocytosis [39]. We next addressed whether estrogen signaling is required for phagocytosis function of macrophage infiltrated in inflamed muscle. For that, CTX myoinjury was performed on OVX mice or untreated control mice, followed by green fluorescent Lum injection into inflamed TA muscle 1d after myoinjury. We found that the uptake of the injected Lum by intramuscular F4/80 $0^{+}$cells in OVX mice was $50 \%$ lower than that in control mice (Fig. 3e). This data suggested that estrogen signaling may have a role in the macrophages phagocytosis and clearance on dying cells in the damaged/regenerating skeletal muscle.

\section{Estrogen signaling affects on accumulation and function of CD4 T cells in damaged muscle}

Muscle antigens have been shown to induce migration of $\mathrm{T}$ lymphocytes to the endomysium or perimysium after myoinjury [40, 41]. To probe whether estrogen signaling is involved in the intramuscular $\mathrm{T}$ cell infiltration, we conducted double immunostaining to assess the presence of $\mathrm{CD}^{+} \mathrm{T}$ cells $\left(\mathrm{CD} 3 \varepsilon^{+} \mathrm{CD} 8 \alpha^{+}\right)$and $\mathrm{CD} 4^{+} \mathrm{T}$ cells $\left(\mathrm{CD} 3 \varepsilon^{+} \mathrm{CD} 4^{+}\right)$in CTX-damaged muscle of ovariectomized female mice. Unexpectedly, we did not find a remarkable number difference of $\mathrm{CD}^{+} \mathrm{T}$ cell in damaged muscle between OVX and control mice (data not shown). Instead, following ovariectomy, an increased ratio of $\mathrm{CD}^{+} \mathrm{T}$ cells were found in damaged muscle (Fig. 4a). To further ascertain whether estrogen signaling affects on intramuscular $\mathrm{CD} 4^{+} \mathrm{T}$ cell phenotypes, we examined the frequency of $\mathrm{T}$ helper-1 (Th1), $\mathrm{T}$ helper-2 (Th2), and T helper-17 (Th17) cells among muscle-infiltrated $\mathrm{CD}^{+} \mathrm{T}$ cell, by the FACS analyzing of the expression of IFN- $\gamma$, IL-4, and IL-17 in those cells. Our results showed that the frequency of IFN $-\gamma^{+} \mathrm{CD} 4^{+}$cells was significantly increased in the inflamed muscle of ovariectomized mice compared to controls (Fig. 4b), suggesting that estrogen signaling is required for suppressing Th1 response in damaged muscle. To definitively establish this point, we isolated $\mathrm{CD}^{+} \mathrm{CD} 4^{+} \mathrm{T}$ cells from 6d-damaged TA muscle of female mice that received OVX or not, and examined gene levels of cytokine IFN- $\gamma$, IL-4, and IL-17, as well the levels of the Th1-specifying transcription factor T-bet, Th2 factor IRF4, and Th17 factor STAT3 by qRT-PCR analysis. In line with the FACS results, the increased mRNA expression of IFN- $\gamma$ and T-bet was seen in $\mathrm{CD}^{+}{ }^{+} \mathrm{T}$ cells isolated from inflamed muscle of OVX mice, comparing to that of control mice (Fig. 4c).

Acute myoinjury provokes the local accumulation of a special population of $\mathrm{CD}^{+}{ }^{+} \mathrm{Foxp}^{+}$regulatory $\mathrm{T}$ cells (Tregs) within days, which exerts immunosuppressive actions, and promotes muscle repair [42, 43]. Some findings reveal a role for a Foxp3-dependent mechanism of $\mathrm{E}_{2}$ control of peripheral $\mathrm{T}$ cell tolerance [44]. To determine whether estrogen signaling affects on Tregs infiltration and function, we investigated Tregs accumulation in CTX-damaged TA muscle from female mice received ovariectomy or not, on day 6 post-myoinjury. Interestingly, despite the increase of $\mathrm{CD}^{+} \mathrm{T}$ cell population in damaged muscle of ovariectomized mice (Fig. 4a), we monitored a significant decrease for the percentage of $\mathrm{CD} 4^{+} \mathrm{CD} 25^{+} \mathrm{Foxp}^{+} \mathrm{T}$ cells in inflamed muscle (Fig. 5a). Given the reported roles of Tregs in skeletal muscle repair [42, 43], we suppose myofiber regeneration delay in 4OHT administered or ovariectomized mice may be partly reasoned by the loss of estrogen signaling restrained Tregs accumulation in damaged muscle.

Previous study has shown that T-bet promotes expression of the chemokine receptor CXCR3 on Treg cells, and T-bet ${ }^{+}$Treg cells accumulated at sites of Th1-mediated inflammation [45]. Since we monitored the elevation of Th1 response in damaged muscle of 


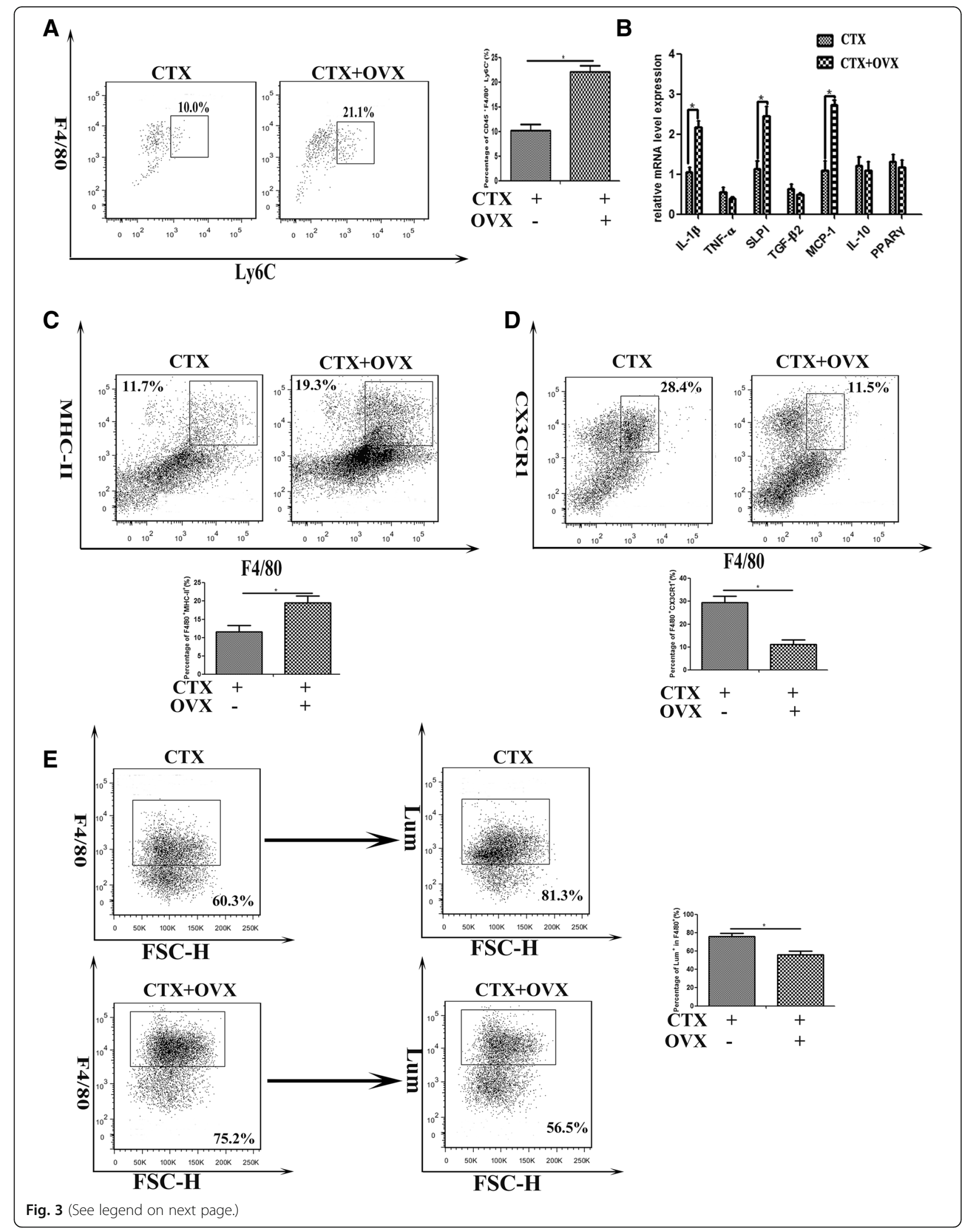


(See figure on previous page.)

Fig. 3 Estrogen signaling effects on the phenotype and function of macrophage infiltrated in inflamed muscle. a FACS analysis of the proportion of Ly- $6 C^{+} \mathrm{F} 4 / 80^{+}$cells in CD45-gated cells isolated from TA muscle on day 3 post-injury, in OVX or intact mice. $\mathbf{b}$ mRNA levels of IL-1 $\beta$, SLPI, MCP-1, TNF-a, TGF- 32 , IL-10, and PPARY were quantified by qRT-PCR in CD $45^{+} F 4 / 80^{+}$cells isolated from inflamed muscle on day 3 post-injury in OVX or intact female mice. c FACS analysis of the proportion of $C D 45^{+} \mathrm{F} 4 / 80^{+} \mathrm{MHC}-\mathrm{II}^{+}$cells isolated from inflamed muscle of OVX or intact female mice. $\mathbf{d}$ FACS analysis of the proportion of $\mathrm{CD} 45^{+} \mathrm{F} 4 / 8 \mathrm{O}^{+} \mathrm{CX} 3 \mathrm{CR} 1^{+}$cells isolated from inflamed muscle of OVX or intact female mice. e FACS analysis of the uptake of the injected Lumispheres by $\mathrm{CD} 45^{+} \mathrm{F} 4 / 80^{+}$cells isolated from inflamed muscle of OVX or intact female mice. Data are representative of two independent experiments performed with three mice per group. One-way ANOVA was used for multiple comparisons $\left({ }^{*} p<0.05\right)$

ovariectomized mice, we next addressed T-bet expression in muscle-infiltrated Treg cells. We exhibited that in the absence of estrogen signaling, T-bet ${ }^{+}$Foxp $3^{-}$cells significantly increased in inflamed muscle, but $\mathrm{T}^{-}$bet $^{+-}$ Foxp $^{+}$cells markedly reduced (Fig. 5b). In order to evaluate the effect of estrogen signaling on Treg cell function, we examined the expression of CTLA-4, which is required for Treg suppressive function [46], on $\mathrm{CD} 4{ }^{+} \mathrm{CD} 25^{+}$cells gated from inflamed muscle. Not surprisingly, we observed the significantly decreased frequency of $\mathrm{CD} 25^{+} \mathrm{CTLA}-4^{+}$cells in the inflamed muscle of OVX mice, comparing to that of control mice (Fig. 5c). Thus our data outline that after acute damage, the upregulated estrogen signaling prompts to Treg cell accumulation in damaged muscle, which is favorable for suppressing of Th1 responses, and for promoting to muscle regeneration.

\section{Estrogen signaling affects on intrinsic immunological behaviors of muscle cells}

Myoblasts and myotubes can express a surprising variety of immunologically important molecules, including class I/II major histocompatibility complex (MHC-I/II) and costimulatory molecules in the presence of IFN- $\gamma$ or other proinflammatory cytokines [47, 48]; this suggests that, under proinflammatory environment, muscle cells can actively participate in local immune reactions. We have demonstrated that estrogen signaling contributed to muscle inflammation response, which could reflect that estrogen signaling possibly affects on intrinsic immunological capacities of muscle cells, like it does for immune cells. To clarify this point, we next evaluated the effects of estrogen signaling on immunological behaviors of muscle cells induced by IFN- $\gamma$. For that, cultured and then horse serum-differentiated $\mathrm{C}_{2} \mathrm{C}_{12}$ cells were treated with $\beta$-estradiol or 4-OHT, separately. We found that $\mathrm{C}_{2} \mathrm{C}_{12}$ cells survived well in $\beta$-estradiol- or 4-OHT-added medium, and can be successfully induced to form multinucleated myotubes under horse serum administration (Fig. 6a). In this experimental setting, differentiated myotubes upregulated protein levels of MHC-I molecule $\mathrm{H}-2 \mathrm{~K}^{\mathrm{b}}$, MHC-II molecule H2-Ea, and TLR3 under IFN- $\gamma$ stimulation (Fig. 6b), which imply that muscle cells gain properties relevant for driving the immune response under inflammatory environment. Consistently, we found that $\mathrm{C}_{2} \mathrm{C}_{12}$ myotubes received IFN- $\gamma$ stimuli upregulated protein level of ER $\beta$, and the adding of $\beta$-estradiol further enhanced ER $\beta$ level (Fig. 6b). In $\beta$-estradiol-treated myotubes, we detected a significant protein level downregulation of $\mathrm{H}-2 \mathrm{~K}^{\mathrm{b}}, \mathrm{H} 2-\mathrm{Ea}$, and TLR3 under IFN- $\gamma$ stimulation. Instead, 4-OHT induced a remarkable upregulation for these molecules (Fig. 6b).

The final detrimental or beneficial effect of the inflammatory response on muscle repair is influenced by specific interactions between inflammatory mediators that act as positive and/or negative regulators to coordinate local and systemic inflammatory-related events and modulate muscle repair process $[49,50]$. To evaluate more directly how immunological capacities of muscle cells is affected by estrogen signaling, we next analyzed the expression of the selected proinflammatory cytokines involving IL-1 and IL-6, anti-inflammatory cytokines involving TGF- $\beta$ and IL-10, and the macrophage-sourced chemokines involving MCP1 and MIP-1 $\alpha$, which have been associated with the preferential biological role during the muscle damage-induced inflammation response [51], in differentiated $\mathrm{C}_{2} \mathrm{C}_{12}$ cells treated with $\beta$ estradiol- or 4-OHT, separately. Our qPCR analysis demonstrated, in the presence of IFN- $\gamma$, that IL-10 expression was significantly inhibited by 4-OHT administration, but promoted by $\beta$-estradiol (Fig. 6c). $\beta$-estradiol treatment resulted in a significant mRNA levels downregulation of proinflammatory IL-1 and IL-6 (Fig. 6c). In contrast, 4-OHT stimulated a conspicuous increase of these two cytokines in myotubes (Fig. 6c). Similarly to what was observed above, we noticed that after changing of estrogen level artificially in vitro, the expression of macrophage-sourced chemokines in muscle cells was altered: $\beta$-estradiol treatment effectively diminished MCP1 levels, but not for MIP-1 $\alpha$. Conversely, 4-OHT induced a striking increase in the production of MCP-1 (Fig. 6c). Taken together, these results collectively suggest that estrogen signaling is crucial for regulating the intrinsic immune behaviors of muscle cells.

\section{Discussion}

In the clinic, it was noted that after the acute trauma, the females were comparatively insensitive to the injury 


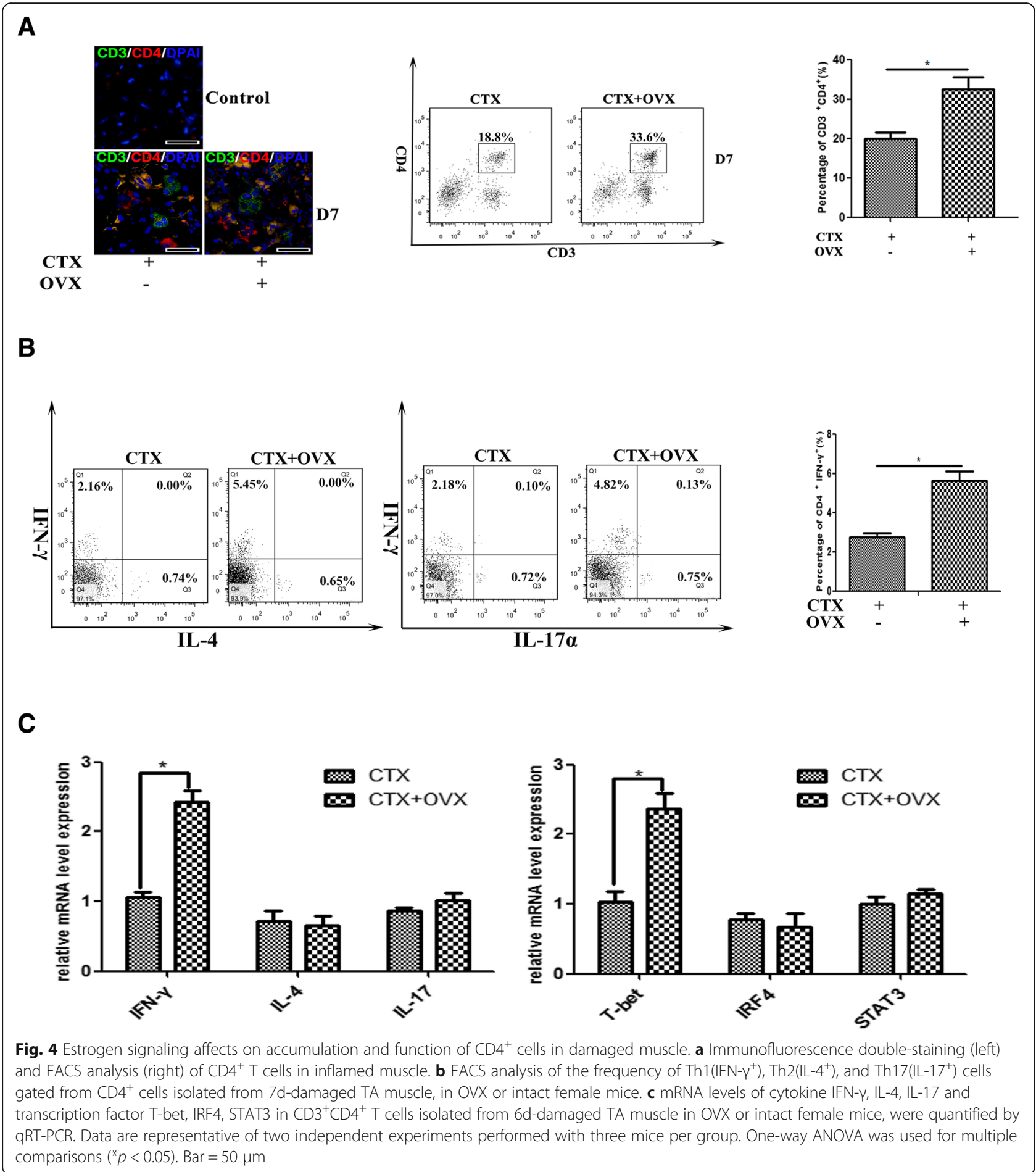

and had better function recovery than the male. This sexual difference in the damaged tissue or organs protection effect was related with the sex hormone levels in the blood circulation and their possible effects on traumatic insult [15-19]. There is evidence showing the serum $E_{2}$ level significantly increased in the early stage in male and female acute traumatic patients $[15,20]$.
While, recent studies indicated that estrogen influences the immunologic responses to traumatic insult in animals. Claudia H. Tambeli et al. proved that estradiol administration in ovariectomized female mice significantly decreased formalin-induced plasma extravasation and neutrophil migration in the temporomandibular joint region, an effect that was blocked by the estrogen receptor 


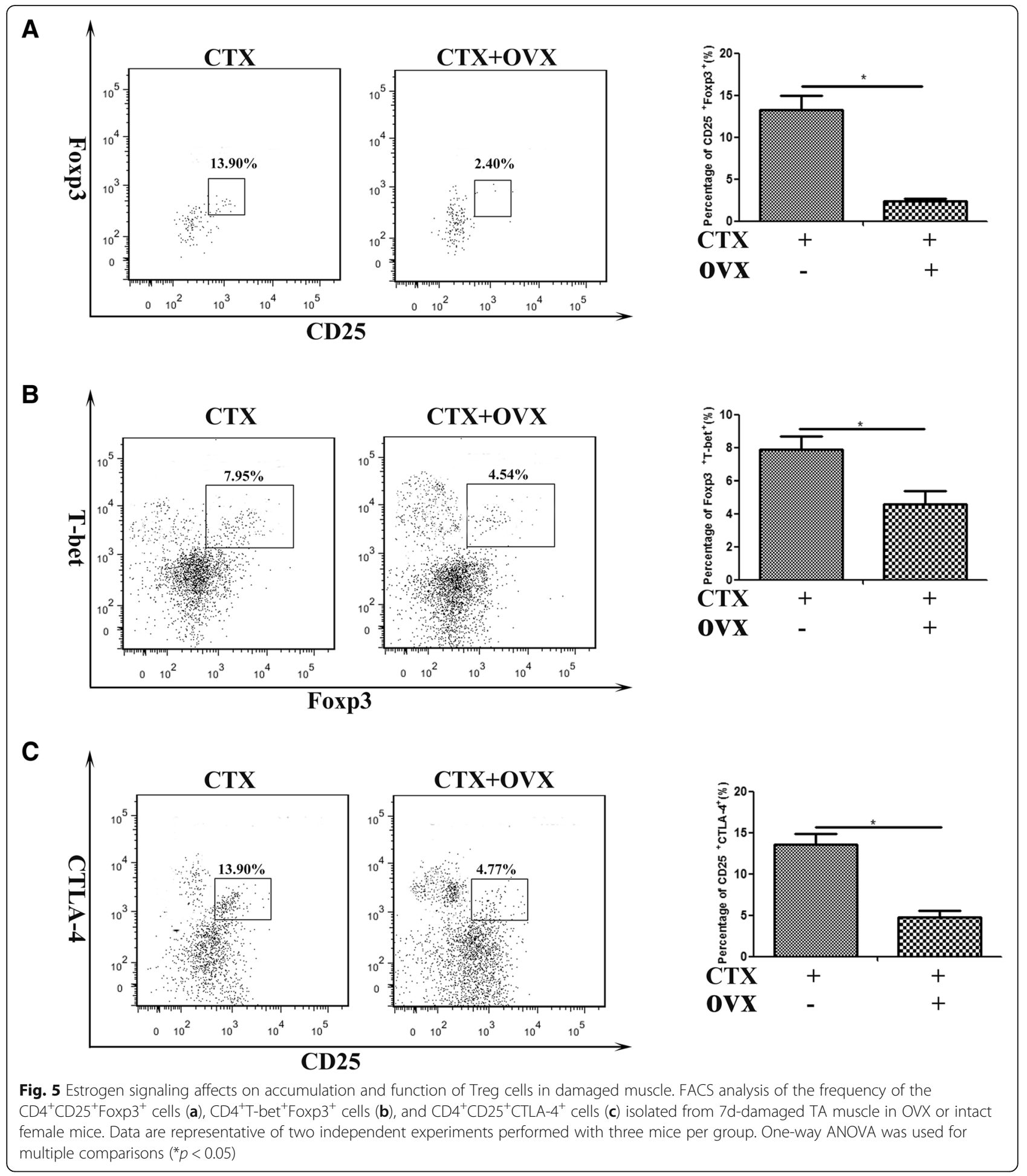

antagonist ICI 182780 [52]. Mukai K. reported that estrogen therapy can reduce the number of wound neutrophils, and reduce the neutrophil adhesion molecule L-selectin, leading to diminished neutrophil localization at sites of inflammation [53]. Using CTX-induced muscle damage model, we monitored a significant elevation for serum $E_{2}$ levels in male and female mice at the early stage, but a rapid decrease at the later stage post-injury reflected an early evolving of estrogen signaling in acute muscle injury procedure. By immunostaining and protein level analysis, we observed the increased ER $\beta$ expression in infiltrated inflammatory cells, and in regenerated myofibers. Previous 


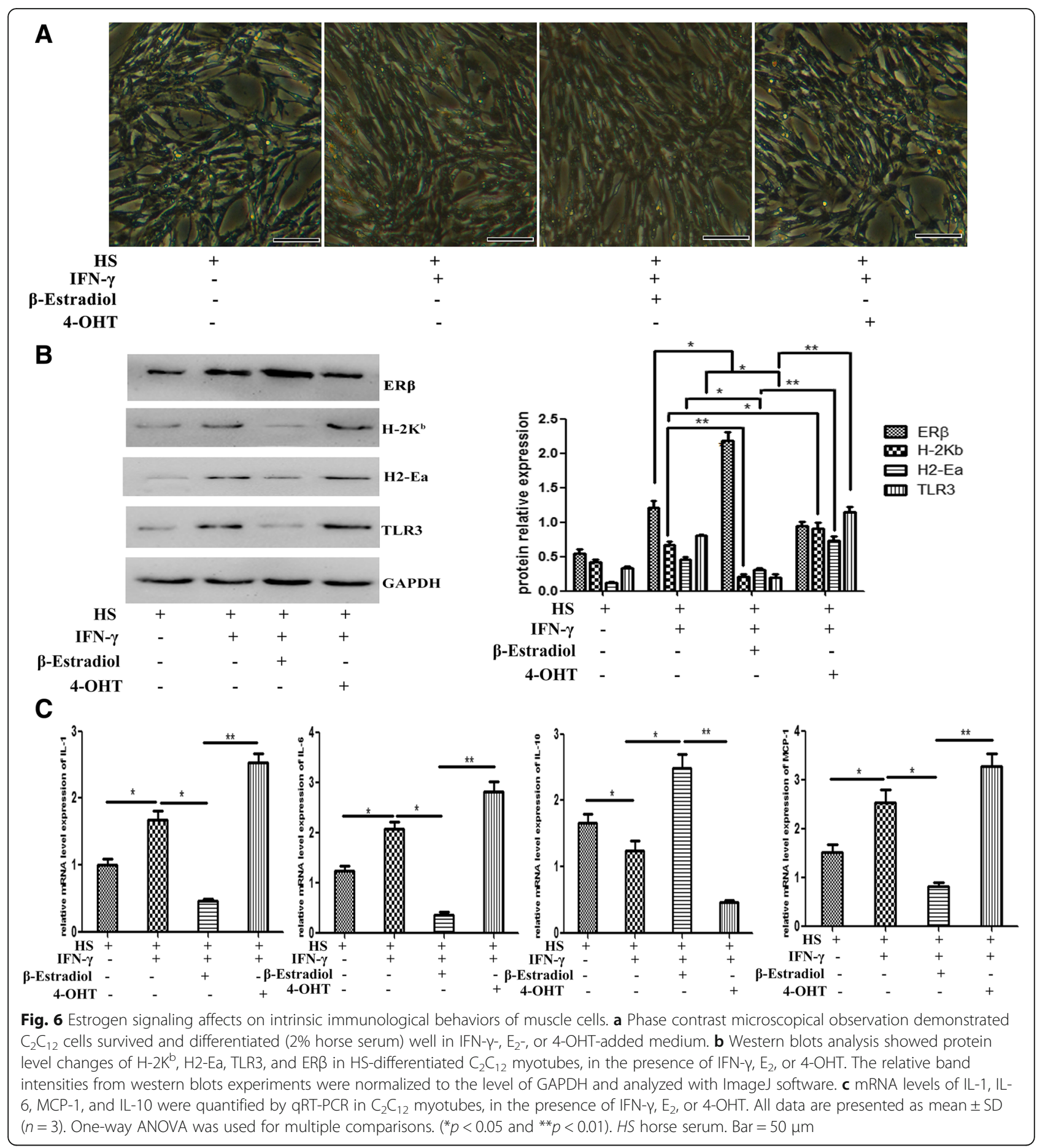

reports suggested that estrogen is required for mediating glucose up-take in skeletal muscle, and for the activation of myogenic precursor cells in response to a myotrauma $[30,31]$; here, we further enriched the issue for its role on muscle inflammation response after myotrauma.

Skeletal muscle is a target tissue for estrogen. Several muscle pathologies are caused, in part, by decreased estrogen levels [29]. In inflamed muscle, neutrophil invasion is exacerbated by ovariectomy (OVX) and attenuated by estrogen treatment, while ER antagonist will attenuate effects of estrogens on leukocyte infiltration in damaged muscle $[54,55] . E_{2}$ is further suggested to reduce inflammatory gene expression in macrophages by inhibiting nuclear factor kappa-light-chain-enhancer of activated B cells (NF-kB) intracellular transport [56]. Our data demonstrated that 4-OHT injection and OVX treatment 
delayed muscle repair, and initiated a more severe monocytes/macrophages infiltration in damaged TA muscle. Our data thus highlight the ability of estrogen to prevent secondary muscle damage by modulating inflammatory dynamics of skeletal muscle after injury. During the inflammatory phase of wound healing, estrogen have been shown to promote alternative macrophage polarization (promote a shift from M1 to M2 subtypes), and thus reduce the expression of proinflammatory cytokines $[53,56]$. Consistently, we monitored the frequency increase of M1 macrophages and the elevation of inflammatory molecules IL- $1 \beta$, SLPI, and MCP- 1 levels in macrophages isolated from damaged muscle of OVX mice, supporting the important roles of estrogen-mediated signaling transduction in dampening muscle inflammation procedure. In addition, we observed that in damaged muscle, macrophage phagocytosis was suppressed following OVX treatment. This is consistent with the previous studies demonstrating that estrogen administration restored liver macrophages phagocytic capacity following trauma-hemorrhage [39], and suggested the role of estrogen signaling in mediating muscle inflammation response and repair.

The mechanism by which estrogen affects T cell biology has not yet been fully elucidated, and the overall picture is complicated by what appears to be a biphasic response to estrogen by $\mathrm{T}$ cells. Indeed, low estrogen states skew the T-helper (Th) response toward a Th1 polarization with associated increased cell-mediated immunity, whereas high doses of estrogen unbalance the Th cell differentiation toward a Th2 phenotype and associated humoral responses [57]. We explored this issue in damaged muscle, and outline that estrogen signaling is key to suppress intramuscular accumulation of $\mathrm{CD}^{+} \mathrm{T}$ cells. In addition, we noticed that in the absence of estrogen signaling, the Th cell differentiation toward a Th1 phenotype in damaged muscle. In female, Treg cells frequency and number increase during the follicular phase due to the increase in estrogen levels, while they decrease during the luteal phase when estrogen is low [9]. ER deletion in T cells contributed to the reduction of $\mathrm{T}$ cell activation and proliferation and increasing the expression of Foxp3, which encodes a critical transcription factor for the differentiation and function of regulatory $\mathrm{T}$ cells. Under iTreg conditions, the addition of $E_{2}$ enhanced the frequency of Foxp $^{+}$cells [58]. Our study suggests that in inflamed muscle, the accumulation and function of Treg cells depends on estrogen level, at least in part, which is favorable for Th1 responses suppression. It has been reported that after acute myoinjury, Treg cells dampens proinflammatory macrophages by reigning in a local IFN $-\gamma$ response [38]. Therefore, according to our results, we could speculate that in inflamed muscle, estrogen signaling dampens proinflammatory macrophages by increasing the Treg cells induced-Th1 response suppression.
Estrogen has been shown to regulate terminal differentiation and survival of antigen-presenting cell (APCs). Seillet et al. reported the effects of $17 \beta$-estradiol on the functional response of steady-state and activated DCs. Specifically, $E_{2}$ boosts the differentiation and effector functions of inflammatory DCs derived from GM-CSFstimulated myeloid precursors, through IFN regulatory factor (IRF)-4 upregulation [59]. This finding aligns with previous studies where it was shown that $\mathrm{E}_{2}$ potentiates and sustains GM-CSF induction of IRF4 in vitro and in vivo [60]. Estrogens also affect the behavior of mature DCs. The study by Siracusa et al. reported that DCs exposed to estrogens in vitro displayed an increase in IFN $\gamma$ ${ }^{+}$killer DCs $\quad\left(\mathrm{CD} 11 \mathrm{c}^{+} \mathrm{MHC}\right.$ class $\mathrm{II}^{+} \mathrm{CD} 49 \mathrm{~b}^{+} \mathrm{Nk} 1.1^{\text {high }}$ phenotype) [61]. Skeletal muscle cells have been proposed to be the facultative APCs. Cultured human myoblasts express constitutively the classical human leukocyte (HLA) class I antigens, TLR3 and TLR7, and the expression level is increased by proinflammatory cytokines (e.g., IFN- $\gamma$, TNF- $\alpha$, IL- $1 \alpha$, etc.), which hints that muscle cells can actively participate in local immune reactions $[47,48]$. In mice, ER $\beta$ is the predominant ER isoform [28]. In agreement, we detected the increased ER $\beta$ expression in inflamed muscle tissue and in regenerated myofibers. In vitro, we observed the obvious expression upregulation of $\mathrm{H}-2 \mathrm{~K}^{\mathrm{b}}$, TLR3, and $\mathrm{H} 2-\mathrm{Ea}$ in the differentiated $\mathrm{C}_{2} \mathrm{C}_{12}$ myotubes in the presence of proinflammatory IFN- $\gamma$. Moreover, we provide evidence for a suppressive role of estrogen signaling in the intrinsic immune behaviors of muscle cells, since we detected a significant downregulation of $\mathrm{H}-2 \mathrm{~K}^{\mathrm{b}}, \mathrm{H} 2-\mathrm{Ea}$, and TLR3 levels and some proinflammatory cytokines in $\beta$-Estradiol-treated $\mathrm{C}_{2} \mathrm{C}_{12}$ myotubes, but a remarkable upregulation in 4-OHTtreated myotubes, under IFN- $\gamma$ stimulation.

\section{Conclusions}

Collectively, our data suggest that estrogen is a positive intervention factor for muscle inflammatory response. In vivo, estrogen devotes to reduce inflammatory damage of skeletal muscle, through its effects on controlling intramuscular infiltration of monocytes/macrophages and the transition of proinflammatory M1 to the anti-inflammatory M2 macrophages, affecting accumulation and function of Treg cells, and suppressing Th1 response in damaged muscle. Our findings also imply an inhibition effect of estrogen on the intrinsic immune behaviors of muscle cells.

\section{Abbreviations}

4-OHT: 4-Hydroxytamoxifen; APC: Antigen-presenting cell; CTX: Cardiotoxin; DC: Dendritic cell; DMEM: Dulbecco's modified Eagle's medium; E2: Estradiol; ERs: Estrogen receptors; FBS: Fetal bovine serum; GAPDH: Glyceraldehyde-3phosphate dehydrogenase; GM-CSF: Granulocyte-macrophage colony stimulating factor; HLA: Human leukocyte; HS: Horse serum; IFN- $\gamma$ : InterferonY; IRF: Interferon regulatory factor; Lum: Lumispheres; MHC-I/II: Class I/II major histocompatibility complex; NF-KB: Nuclear factor kappa-light-chain-enhancer 
of activated B cells; NK: Natural killer; OVX: Ovariectomy; TA: Tibialis anterior; TGF- $\beta$ : Transforming growth factor- $\beta$; TLR: Toll-like receptors

\section{Acknowledgements}

Not applicable.

\section{Funding}

This study has been supported by grants from the National Natural Science Foundation of China (81572102), National Key Research and Development Plan (2017YFC1105003), and Director Foundation of Nanfang Hospital of Southern Medical University (2018B017).

\section{Availability of data and materials}

All data generated or analyzed during this study are included in this published article.

\section{Authors' contributions}

All authors were involved in drafting the article or revising it critically for important intellectual content, and all authors approved the final version to be published. HL had full access to all of the data in the study and takes responsibility for the integrity of the data and the accuracy of the data analysis. Study conception and design: $\mathrm{HL}, \mathrm{GW}$; Acquisition of data: $\mathrm{ZHL}, \mathrm{TH}$; Analysis and interpretation of data: ZHL, TH, JWX, RCG, JO, GW, HL.

\section{Ethics approval and consent to participate}

All animal experimental protocols were approved by Southern Medical University Institutional Animal Care and Use Committee.

\section{Consent for publication}

Not applicable.

\section{Competing interests}

The authors declare that they have no competing interests.

\section{Publisher's Note}

Springer Nature remains neutral with regard to jurisdictional claims in published maps and institutional affiliations.

\section{Received: 16 January 2019 Accepted: 17 July 2019}

\section{References}

1. Mirandola L, Wade R, Verma R, Pena C, Hosiriluck N, Figueroa JA, et al. Sexdriven differences in immunological responses: challenges and opportunities for the immunotherapies of the third millennium. Int Rev Immunol. 2015:34:134-42.

2. Kovats S. Estrogen receptors regulate innate immune cells and signaling pathways. Cell Immunol. 2015:294:63-9.

3. Jaillon S, Berthenet K, Garlanda C. Sexual dimorphism in innate immunity. Clin Rev Allergy Immunol. 2017;56(3):308-21.

4. Kanda N, Tamaki K. Estrogen enhances immunoglobulin production by human pbmcs. J Allergy Clin Immunol. 1999:103:282-8.

5. Cyster JG, Goodnow CC. Protein tyrosine phosphatase 1c negatively regulates antigen receptor signaling in $b$ lymphocytes and determines thresholds for negative selection. Immunity. 1995:2:13-24.

6. Dinesh RK, Hahn BH, Singh RP. Pd-1, gender, and autoimmunity. Autoimmun Rev. 2010;9:583-7.

7. Merino R, Ding L, Veis DJ, Korsmeyer SJ, Nunez G. Developmental regulation of the bcl-2 protein and susceptibility to cell death in b lymphocytes. EMBO J. 1994;13:683-91.

8. Sato S, Tuscano JM, Inaoki M, Tedder TF. Cd22 negatively and positively regulates signal transduction through the $b$ lymphocyte antigen receptor. Semin Immunol. 1998;10:287-97.

9. Arruvito L, Sanz M, Banham AH, Fainboim L. Expansion of $c d 4+c d 25+$ and foxp3+ regulatory $t$ cells during the follicular phase of the menstrual cycle: implications for human reproduction. J Immunol. 2007;178:2572-8.

10. Mo R, Chen J, Grolleau-Julius A, Murphy HS, Richardson BC, Yung RL. Estrogen regulates ccr gene expression and function in t lymphocytes. J Immunol. 2005;174:6023-9.

11. Bouman A, Heineman MJ, Faas MM. Sex hormones and the immune response in humans. Hum Reprod Update. 2005;11:411-23.
12. Garcia-Duran M, de Frutos T, Diaz-Recasens J, Garcia-Galvez G, Jimenez A, Monton $\mathrm{M}$, et al. Estrogen stimulates neuronal nitric oxide synthase protein expression in human neutrophils. Circ Res. 1999;85:1020-6.

13. Miyagi M, Aoyama H, Morishita M, Iwamoto Y. Effects of sex hormones on chemotaxis of human peripheral polymorphonuclear leukocytes and monocytes. J Periodontol. 1992;63:28-32.

14. Hao S, Zhao J, Zhou J, Zhao S, Hu Y, Hou Y. Modulation of 17beta-estradiol on the number and cytotoxicity of nk cells in vivo related to $\mathrm{mcm}$ and activating receptors. Int Immunopharmacol. 2007;7:1765-75.

15. Choudhry MA, Bland KI, Chaudry IH. Gender and susceptibility to sepsis following trauma. Endocr Metab Immune Disord Drug Targets. 2006;6:127-35.

16. Sperry JL, Minei JP. Gender dimorphism following injury: making the connection from bench to bedside. J Leukoc Biol. 2008:83:499-506.

17. Groswasser Z. Gender and traumatic brain injury. J Neurosurg. 2001;94:862-4.

18. Ponsford JL, Myles PS, Cooper DJ, McDermott FT, Murray LJ, Laidlaw J, et al. Gender differences in outcome in patients with hypotension and severe traumatic brain injury. Injury. 2008;39:67-76.

19. Brown CM, Suzuki S, Jelks KA, Wise PM. Estradiol is a potent protective, restorative, and trophic factor after brain injury. Semin Reprod Med. 2009;27:240-9.

20. Gang W, Limin X, Yang W, Zhanzhi W, Lijun X. The effects of craniocerebral and extracranial trauma on the changes in serum testosterone and estradiol in the early stage and their clinical significance. J Trauma Acute Care Surg. 2013;74:254-8.

21. Horng HC, Chang WH, Yeh CC, Huang BS, Chang CP, Chen YJ, et al. Estrogen effects on wound healing. Int J Mol Sci. 2017;18(11):2325. https:// doi.org/10.3390/ijms18112325

22. Mor G, Sapi E, Abrahams VM, Rutherford T, Song J, Hao XY, et al. Interaction of the estrogen receptors with the fas ligand promoter in human monocytes. J Immunol. 2003;170:114-22.

23. Komi J, Lassila O. Nonsteroidal anti-estrogens inhibit the functional differentiation of human monocyte-derived dendritic cells. Blood. 2000; 95:2875-82

24. Laffont S, Seillet C, Guery JC. Estrogen receptor-dependent regulation of dendritic cell development and function. Front Immunol. 2017:8:108.

25. Charge SB, Rudnicki MA. Cellular and molecular regulation of muscle regeneration. Physiol Rev. 2004;84:209-38.

26. Tidball JG. Inflammatory processes in muscle injury and repair. Am J Phys Regul Integr Comp Phys. 2005;288:R345-53.

27. Ekenros L, Papoutsi Z, Friden C, Dahlman Wright K, Linden HA. Expression of sex steroid hormone receptors in human skeletal muscle during the menstrual cycle. Acta Physiol (Oxf). 2017;219:486-93.

28. Milanesi L, Vasconsuelo A, de Boland AR, Boland R. Expression and subcellular distribution of native estrogen receptor beta in murine $\mathrm{c} 2 \mathrm{c} 12$ cells and skeletal muscle tissue. Steroids. 2009;74:489-97.

29. Kahlert S, Grohe C, Karas RH, Lobbert K, Neyses L, Vetter H. Effects of estrogen on skeletal myoblast growth. Biochem Biophys Res Commun. 1997;232:373-8

30. Velders M, Diel P. How sex hormones promote skeletal muscle regeneration. Sports Med. 2013;43:1089-100

31. Hevener AL, Zhou Z, Drew BG, Ribas V. The role of skeletal muscle estrogen receptors in metabolic homeostasis and insulin sensitivity. Adv Exp Med Biol. 2017:1043:257-84

32. Johnson ML, Ho CC, Day AE, Walker QD, Francis R, Kuhn CM. Oestrogen receptors enhance dopamine neurone survival in rat midbrain. J Neuroendocrinol. 2010;22:226-37.

33. Van Sinderen ML, Steinberg GR, Jorgensen SB, Honeyman J, Chow JD, Herridge KA, et al. Effects of estrogens on adipokines and glucose homeostasis in female aromatase knockout mice. PLoS One. 2015;10:e0136143.

34. Fan P, Agboke FA, Cunliffe HE, Ramos P, Jordan VC. A molecular model for the mechanism of acquired tamoxifen resistance in breast cancer. Eur J Cancer. 2014;50:2866-76.

35. Wang Y, Shoemaker R, Thatcher SE, Batifoulier-Yiannikouris F, English VL, Cassis LA. Administration of 17beta-estradiol to ovariectomized obese female mice reverses obesity-hypertension through an ace2-dependent mechanism. Am J Physiol Endocrinol Metab. 2015;308:E1066-75.

36. Brunelli $S$, Rovere-Querini P. The immune system and the repair of skeletal muscle. Pharmacol Res. 2008:58:117-21.

37. Tidball JG, Villalta SA. Regulatory interactions between muscle and the immune system during muscle regeneration. Am J Phys Regul Integr Comp Phys. 2010;298:R1173-87. 
38. Panduro M, Benoist C, Mathis D. Treg cells limit IFN-gamma production to control macrophage accrual and phenotype during skeletal muscle regeneration. Proc Natl Acad Sci U S A. 2018;115:E2585-93.

39. Hsieh CH, Nickel EA, Chen J, Schwacha MG, Choudhry MA, Bland Kl, et al. Mechanism of the salutary effects of estrogen on kupffer cell phagocytic capacity following trauma-hemorrhage: pivotal role of akt activation. J Immunol. 2009;182:4406-14.

40. Malmstrom V, Venalis P, Albrecht I. T cells in myositis. Arthritis Res Ther. 2012;14:230.

41. Liao H, Franck E, Freret M, Adriouch S, Baba-Amer Y, Authier FJ, et al. Myoinjury transiently activates muscle antigen-specific $\mathrm{CD}^{+} \mathrm{t}$ cells in lymph nodes in a mouse model. Arthritis Rheum. 2012;64:3441-51.

42. Burzyn D, Kuswanto W, Kolodin D, Shadrach JL, Cerletti M, Jang Y, et al. A special population of regulatory t cells potentiates muscle repair. Cell. 2013; 155:1282-95.

43. Schiaffino S, Pereira MG, Ciciliot S, Rovere-Querini P. Regulatory t cells and skeletal muscle regeneration. FEBS J. 2017;284:517-24.

44. Fan XL, Duan XB, Chen ZH, Li M, Xu JS, Ding GM. Lack of estrogen downregulates cxcr 4 expression on treg cells and reduces treg cell population in bone marrow in ovx mice. Cell Mol Biol (Noisy-le-grand). 2015;61:13-7.

45. Koch MA, Tucker-Heard G, Perdue NR, Killebrew JR, Urdahl KB, Campbell DJ. The transcription factor t-bet controls regulatory $\mathrm{t}$ cell homeostasis and function during type 1 inflammation. Nat Immunol. 2009;10:595-602.

46. Walker LS. Treg and ctla-4: two intertwining pathways to immune tolerance, J Autoimmun. 2013:45:49-57.

47. Wiendl $\mathrm{H}$, Hohlfeld R, Kieseier BC. Immunobiology of muscle: advances in understanding an immunological microenvironment. Trends Immunol. 2005;26:373-80.

48. Ding M, Huang T, Zhu R, Gu R, Shi D, Xiao J, et al. Immunological behavior analysis of muscle cells under ifn-gamma stimulation in vitro and in vivo. Anat Rec (Hoboken). 2018:301:1551-63.

49. Joanisse S, Parise G. Cytokine mediated control of muscle stem cell function. Adv Exp Med Biol. 2016;900:27-44.

50. Philippou A, Maridaki M, Theos A, Koutsilieris M. Cytokines in muscle damage. Adv Clin Chem. 2012;58:49-87.

51. Arango Duque G, Descoteaux A. Macrophage cytokines: involvement in immunity and infectious diseases. Front Immunol. 2014:5:491.

52. Torres-Chavez KE, Sanfins JM, Clemente-Napimoga JT, Pelegrini-Da-Silva A, Parada CA, Fischer $L$, et al. Effect of gonadal steroid hormones on formalininduced temporomandibular joint inflammation. Eur J Pain. 2012;16:204-16.

53. Mukai K, Urai T, Asano K, Nakajima Y, Nakatani T. Evaluation of effects of topical estradiol benzoate application on cutaneous wound healing in ovariectomized female mice. PLoS One. 2016;11:e0163560.

54. McClung JM, Davis JM, Carson JA. Ovarian hormone status and skeletal muscle inflammation during recovery from disuse in rats. Exp Physiol. 2007; 92:219-32.

55. McClung JM, Davis JM, Wilson MA, Goldsmith EC, Carson JA. Estrogen status and skeletal muscle recovery from disuse atrophy. J Appl Physiol (1985). 2006;100:2012-23.

56. Ghisletti S, Meda C, Maggi A, Vegeto E. 17beta-estradiol inhibits inflammatory gene expression by controlling nf-kappab intracellular localization. Mol Cell Biol. 2005;25:2957-68.

57. Pernis AB. Estrogen and cd4t t cells. Curr Opin Rheumatol. 2007;19:414-20.

58. Mohammad I, Starskaia I, Nagy T, Guo J, Yatkin E, Vaananen K, et al. Estrogen receptor alpha contributes to $t$ cell-mediated autoimmune inflammation by promoting t cell activation and proliferation. Sci Signal. 2018;11(526):eaap9415. https://doi.org/10.1126/scisignal.aap9415

59. Seillet C, Rouquie N, Foulon E, Douin-Echinard V, Krust A, Chambon P, et al. Estradiol promotes functional responses in inflammatory and steady-state dendritic cells through differential requirement for activation function-1 of estrogen receptor alpha. J Immunol. 2013;190:5459-70.

60. Carreras E, Turner S, Frank MB, Knowlton N, Osban J, Centola M, et al. Estrogen receptor signaling promotes dendritic cell differentiation by increasing expression of the transcription factor irf4. Blood. 2010;115:238-46.

61. Siracusa MC, Overstreet MG, Housseau F, Scott AL, Klein SL. 17beta-estradiol alters the activity of conventional and ifn-producing killer dendritic cells. J Immunol. 2008;180:1423-31.

\section{Ready to submit your research? Choose BMC and benefit from:}

- fast, convenient online submission

- thorough peer review by experienced researchers in your field

- rapid publication on acceptance

- support for research data, including large and complex data types

- gold Open Access which fosters wider collaboration and increased citations

- maximum visibility for your research: over $100 \mathrm{M}$ website views per year

At BMC, research is always in progress.

Learn more biomedcentral.com/submissions 